\title{
Exploring Mexican adolescents' perceptions of environmental health risks: a photographic approach to risk analysis
}

\author{
Explorando as percepções de riscos de saúde ambiental \\ em adolescentes mexicanos: uma abordagem fotográfica \\ para análise de risco
}

\author{
Susanne Börner ${ }^{1}$ \\ Juan Carlos Torrico Albino ${ }^{2}$ \\ Luz María Nieto Caraveo ${ }^{3}$ \\ Ana Cristina Cubillas Tejeda ${ }^{1}$
}

${ }^{1}$ Facultad de Ciencias Químicas, Universidad Autónoma de San Luis Potosí. Av. Dr. Manuel Nava 6, Zona Universitaria. 78210 San Luis Potosí San Luis Potosí México.

Susanne_Boerner@gmx.de ${ }^{2}$ Institute for Technology and Resources Management in the Tropics and Subtropics, Cologne University of Applied Sciences.

${ }^{3}$ Agenda Ambiental, Universidad Autónoma de San Luis Potosí.

\begin{abstract}
The objective of this study was to explore Mexican adolescents' perceptions of environmental health risks in contaminated urban areas, and to test the environmental photography technique as a research tool for engaging adolescents in community-based health research. The study was conducted with 74 adolescents from two communities in the city of San Luis Potosi, Mexico. Participants were provided with disposable cameras and asked to take photographs of elements and situations which they believed affected their personal health both at home and outside their homes. They were also asked to describe each photograph in writing. Photographs and written explanations were analyzed by using quantitative and qualitative content analysis. Risk perception plays a crucial role in the development of Risk Communication Programs (RCPs) aimed at the improvement of community health. The photography technique opens up a promising field for environmental health research since it affords a realistic and concise impression of the perceived risks. Adolescents in both communities perceived different environmental health risks as detrimental to their well-being, e.g. waste, air pollution, and lack of hygiene. Yet, some knowledge gaps remain which need to be addressed.
\end{abstract}

Key words Risk perception, Environmental health risks, Photography, Adolescent health, Environmental education
Resumo Objetivos: Analisar as percepções dos adolescentes mexicanos em relação aos riscos na saúde ambiental em áreas urbanas contaminadas, e testar a técnica da fotografia ambiental da comunidade sobre a percepção de risco local. Métodos: O estudo foi realizado com 74 adolescentes de duas comunidades na cidade de San Luis Potosi, no México. Os participantes receberam câmeras descartáveis e foram convidados a tirar fotografias de elementos e/ou situações em que acreditavam estar afetando sua saúde pessoal dentro ou fora de casa. Solicitou-se também aos participantes a descrição de cada fotografia por escrito. As fotografias e as explicações passaram pela análise de conteúdo quantitativa e qualitativa. Conhecer a percepção de risco dos adolescentes desempenha papel crucial no desenvolvimento de programas de comunicação de risco para a melhoria da saúde da comunidade. A técnica de fotografia é promissora para a pesquisa qualitativa em saúde ambiental por oferecer uma impressão realista e concisa das percepções de risco. Os adolescentes em ambas comunidades perceberam uma ampla gama de riscos de saúde ambientais prejudiciais ao seu bem-estar, por exemplo, resíduos, poluição do ar e falta de higiene. No entanto, ainda existem algumas de conhecimento que devem ser abordados. Palavras-chave Percepção de risco, Riscos de saúde ambiental, Fotografia, Saúde do adolescente, Educação ambiental 


\section{Introduction}

The relationship between the environment and human health is highly complex as human health is threatened by a variety of risks ${ }^{1}$. According to the World Health Organization, environmental health addresses all the physical, chemical, and biological factors external to a person, and all the related factors impacting behaviors. It furthermore includes the assessment and control of those environmental factors that can potentially affect health, aiming at preventing disease and creating health-supportive environments ${ }^{2}$. Children and adolescents in particular represent a highly vulnerable population group which is strongly affected by cumulative environmental risks ${ }^{3,4}$. This can have devastating effects on their future, since adult life - including income, professional opportunities and the occurrence of chronic diseases - is conditioned by the health conditions, education and the development of capacities during childhood and adolescence ${ }^{1,5}$.

Knowing the risk perception of a study group plays a crucial role in the development of specifically tailored risk communication programs for the improvement of community health. Traditionally, risk perception has been approached from a scientific perspective. Yet, over time it has proven necessary to conceive risk as depending on a threefold basis, including physical, material and cognitive aspects ${ }^{6}$. For the purpose of this study, risk perception is understood as the capacity of an individual to interpret a potentially harmful situation based on individual as well as collective beliefs ${ }^{7}$. In other words, it is the subjective assessment of the characteristics and of the gravity of a hazard within a determined socio-environmental sphere grounded in emotions, attitudes, and the knowledge of a situation.

Analyzing adolescents' perception of environmental health risks and quality of life requires particular research techniques require, allow understanding their perspective through stimulate a meaningful involvement in the research process $^{9,10}$. Furthermore adolescents should be enabled to ponder their own conditions in order to assume responsibility in creating healthy communities ${ }^{9}$. Hence, our study seeks to address this gap by testing and evaluating the photography technique as a qualitative tool for engaging adolescents in community-based environmental health research.

Up to the present, researchers have paid little attention to the photography technique. Michael Lesy was the first to discover the importance of images in social research related to the analysis of social behavior. Another pioneer in photography-based research was Fiona Sanz who developed the photobiography approach to analyze conscious and subconscious memories of the past $^{11}$. Other examples of qualitative research involving photography can be found in Dinklage ${ }^{12}$, Fernández-Villanueva et al. ${ }^{13}$, and Corona-Ber$\mathrm{kin}^{14}$. Nonetheless, the application of photography in research on environmental risk perception is a new, very promising field.

Our study was carried out in two heavily polluted communities within the city of San Luis Potosí, Mexico. The first study area, generally referred to as Las Terceras, is a brick-making community in the northern outskirts of the city $^{15}$. A total of 148 brick kilns are operated in the area, and the incineration of waste is a common practice ${ }^{16,17}$. The community suffers from a complex interaction of environmental, social and sanitary health risks with high levels of air, water and soil pollution as well as social conflicts. However, previous studies have indicated that many of the harmful determinants of health are preventable ${ }^{17}$. The exposure to pollutants is aggravated by the lack of separation between living and working spaces, which provokes an increased occurrence of respiratory diseases. Previous studies also identified health risks due to the fluoridation of ground water ${ }^{17,18}$. Also, the pollution of soil and water with animal feces and solid waste, the use of insecticides, the lack of traffic safety, and indoor smoking cause serious damage to community health. Social factors with a detrimental impact on community health include low education levels, overcrowded housing, violence and high crime rate, alcoholism, and the lack of perspectives for young people ${ }^{17,18}$.

The second study area is divided into the adjacent communities Morales and Lomas de los Filtros, which are located in the west of the city, in the vicinity of a metallurgical industrial plant operated since the $1890 \mathrm{~s}^{19}$. Originally composed by a copper foundry as well as an electrolytic zinc refinery, nowadays only the latter is in opera$\operatorname{tion}^{19,20}$. High levels of heavy metals such as lead and arsenic have been detected in air, dust and soil. Previous studies have proven health risks for the community, and for pregnant women and children in particular ${ }^{19-21}$. Further threats to health relate to alcoholism, violence, drug abuse, the lack of traffic safety, fluoridation of drinking water, the incineration of waste, in-house smoking, and the use of insecticides (unpublished results of a study carried out in 2012 by researchers 


\section{Methods}

\section{Study population}

The study involved a sample of 74 children and adolescents aged 11-16 from two primary and two secondary schools in the city of San Luis Potosí. Sampling was based on convenience inclusion criteria, which were grade level, age, residence in the study areas, and the informed consent signed by the parents. The participation of adolescents was voluntary. The sample consisted of 37 boys and 37 girls. Of all 74 participants, 41 students attended primary school and 33 attended secondary school. Also, 33 students lived in the community Las Terceras, and 41 students came from the communities Morales and Lomas de los Filtros. Participating schools were the primary school Profesora Dolores Reyes Velázquez (Las Terceras), the primary school Industrial Minera México (Morales), the secondary school Profesor Juan Andrés Soria García (Las Terceras), and the secondary school Justo A. Zamudio Vargas (Lomas de los Filtros).

\section{Study design}

Each of the 74 participants was provided with a disposable camera containing film for 27 photographs. The process of data collection was semi-structured, since we asked participants to take photographs to respond to specific questions: What is bad for you at home? What is bad for you outside your home? We furthermore asked participants what is good for them at home and outside their home. This paper, however, only presents parts of the results derived from the study.

The selection of questions was based on previous studies on environmental health risks in the communities of Cuatlamayán and Tercera Chica where research had been conducted with children in kindergarten and primary school using drawings ${ }^{18}$. The effectiveness of similar questions had also been proven by Cubillas-Tejeda et

al. ${ }^{21}$ and Coronado-Salas et al. ${ }^{22}$. Furthermore, participants were asked to describe each photo in writing. For this purpose, each student was provided with a notepad. An introductory workshop was held at each of the participating schools in order to explain the activity as well as how to handle the cameras. Students were given approximately three days to take the photographs and to provide the written explanation. The name of each student was noted on his or her camera and notepad in order to facilitate the processing of the working material. Upon developing the film rolls, participants were interviewed in order to answer additional questions.

The analysis of the obtained data was conducted using a mix-method approach which combines quantitative ${ }^{11,23}$ and qualitative content analysis $^{11,24,25}$. The quantitative approach, which is based on a frequency analysis, helps provide a concise overview of the risks that were perceived according to study area and age. The presentation of data in the frequency format makes it possible to identify where future action is needed to address existing knowledge gaps, hence providing an important basis for the development of a local risk communication program. At the same time, the qualitative content analysis of the coded data is considered fundamental, since this allows gaining a deeper understanding of participants' individual perceptions and concerns.

The first step of qualitative data analysis comprised the coding of data into exhaustive thematic categories. The categories were established inductively based on the different elements found in the photographs as well as the written descriptions ${ }^{23}$ (Chart 1). This categorization was carried out separately for questions "What is bad for outside your home?" and "What is bad for you at home?" In terms of quantitative analysis, frequency analysis was conducted based on the coded data. Frequencies were counted for each category per individual without considering the total number of photographs that each participant had taken in each category. Drawing on the frequency analysis, the obtained data was then submitted to statistical analysis in order to illustrate statistically relevant differences between the different age groups (primary or secondary school) and study areas (Las Terceras or Morales/Lomas de los Filtros). To this purpose, a comprehensive set of cross tabulations and Chi2 tests were conducted using the software JMP 10 with the level of statistical significance of $95 \%{ }^{26}$. Furthermore, qualitative content analysis was carried out building on the previous coding frame or categories. Drawing on the coding 


\begin{tabular}{|c|c|}
\hline Established categories & Category description \\
\hline Activities and habits & $\begin{array}{l}\text { It refers to bad habits that are unhealthy, particularly habits related to the use of } \\
\text { technology (TV, computer, video games, etc.). It also includes habits that young } \\
\text { people do not like, such as getting up early. }\end{array}$ \\
\hline Addictions & $\begin{array}{l}\text { It includes elements related to abuse of alcohol and drugs, smoking and other } \\
\text { addictions like gambling machines. }\end{array}$ \\
\hline Animals and pests & $\begin{array}{l}\text { This category contains pictures of animals or pests, such as dogs, snakes, flies, } \\
\text { rats, and others. }\end{array}$ \\
\hline Aspects of the house & $\begin{array}{l}\text { It includes photographs with elements that show bad conditions of the house, } \\
\text { such as holes in the wall, broken windows, etc. }\end{array}$ \\
\hline Waste and soil pollution & $\begin{array}{l}\text { It includes photographs showing the pollution generated by the garbage, } \\
\text { unpaved streets and contaminated soil. }\end{array}$ \\
\hline Junk food & $\begin{array}{l}\text { It refers to elements related to unhealthy foods such as soft drinks, candy, junk } \\
\text { food etc. }\end{array}$ \\
\hline Air and water pollution & $\begin{array}{l}\text { It includes photographs related air pollution by the brick kilns, the incineration } \\
\text { of garbage and water contamination due to feces, garbage, etc. }\end{array}$ \\
\hline Waste of natural resources & $\begin{array}{l}\text { This category includes photographs that refer to the destruction and the } \\
\text { mismanagement of natural resources. }\end{array}$ \\
\hline Dangerous items & $\begin{array}{l}\text { It includes items that may present a danger to children, such as knives, guns, } \\
\text { glasses, gas tanks, boilers, etc. }\end{array}$ \\
\hline Lack of hygiene & It includes pictures that refer to dirt and a poor hygiene at home. \\
\hline Violence & It includes photographs related to the mistreatment of others, including fighting. \\
\hline Traffic & $\begin{array}{l}\text { It contains pictures relate to traffic because of the risk of road accidents and } \\
\text { collisions. }\end{array}$ \\
\hline Vandalism & $\begin{array}{l}\text { It includes photographs with elements related to the destruction of public } \\
\text { property, mainly graffiti. }\end{array}$ \\
\hline
\end{tabular}

frame, the material was systematically structured and analyzed. To this purpose, a cross-section of the material was conducted and relevant examples were selected to highlight fundamental issues that were found across the different cases $^{24,25}$. Finally, a SWOT analysis (strengths, weaknesses, opportunities and threats) was carried out in order to evaluate the photography technique as a qualitative research tool for environmental risk analysis.

The study was approved by the ethics committee of the Faculty for Medicine at the Uni- versidad Autónoma de San Luis Potosí, and written permission was given by the respective educational authorities involved in the project. Additionally, parents were asked for their written informed consent after taking part in an information meeting. Parents were informed that participation was voluntary and that their child could abandon the project at any moment if they wished. They were also provided with a letter which resumed the information provided during the meeting. 


\section{Results}

In this section, the results of the participatory study are presented and discussed in qualitative and quantitative terms. The Figure 1 illustrates the categorization of risks that were perceived by the participants inside their homes according to study area: Las Terceras or Morales/Lomas de los Filtros (Figure 1A) and age: primary school or secondary school (Figure 1B). In the scenario "at home", participants from both study areas, perceived mainly activities such as activities and habits, dangerous items, waste, soil pollution and addictions as harmful to their health (Chart 1,
Figure 2). Fifty-five percent of students from Las Terceras and $63 \%$ of students from Morales /Lomas de los Filtros for instance indicated that they tend to spend too much time on leisure activities related to the use of communication technologies such as computers, video games, cellular phones and television (Figure 2A), distracting them from other activities such as school work (Figure 1A, Category activities and habits). Additionally, $30 \%$ of the students from Las Terceras and 39\% of the students from Morales and Lomas de los Filtros identified dangerous items at home as a harmful factor (Figure 1A), such as loose cables, boilers (Figure $2 \mathrm{~B}$ ), gas tanks, open fire and un-
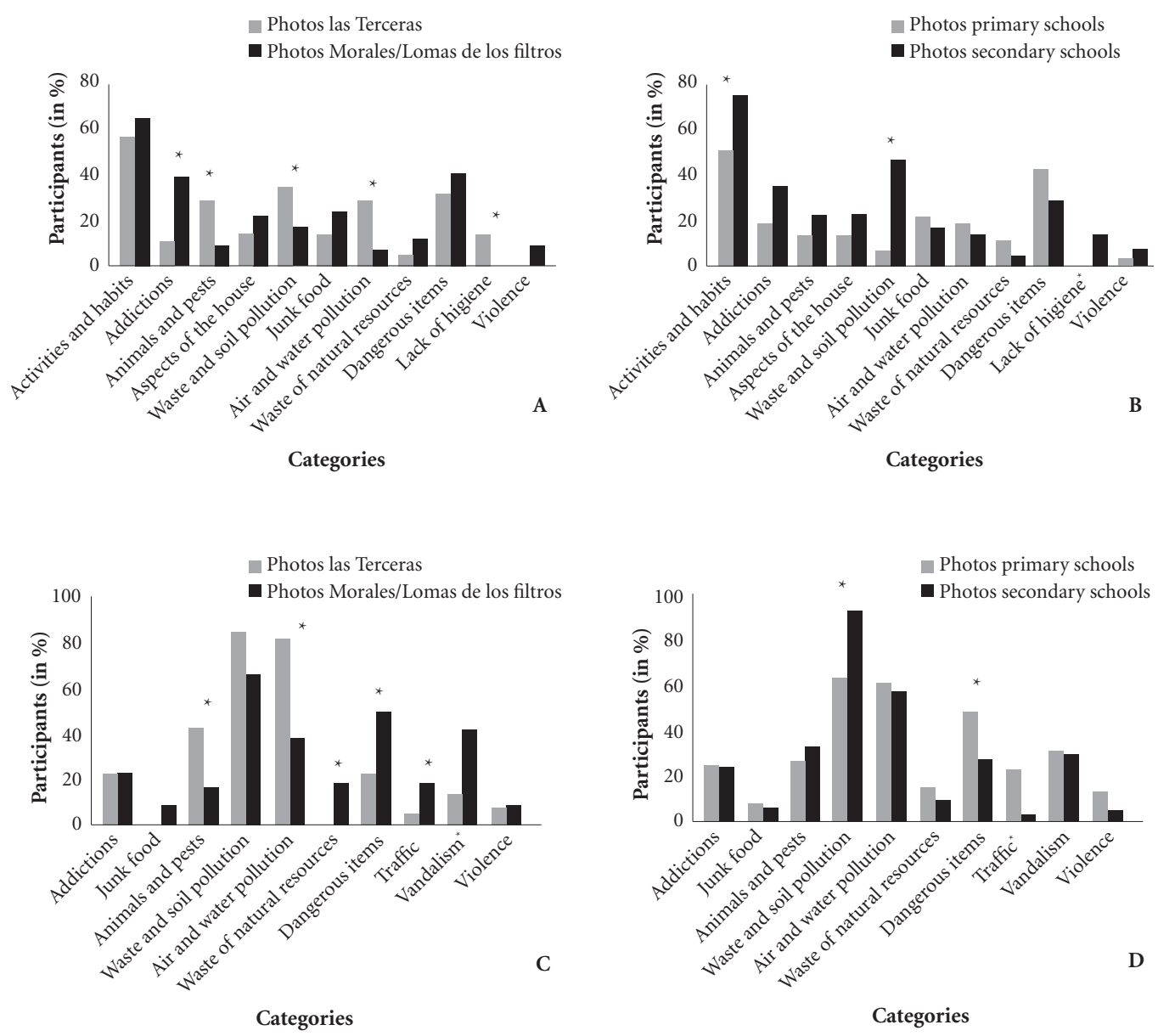

Figure 1. Risks perceived by the students (A) Risks perceived inside their home according to study area: Las Terceras and Morales/Lomas de los Filtros (B) Risks perceived inside their home according to age: primary school and secondary school. (C) Risks perceived outside their home according to study area: Las Terceras and Morales/Lomas de los Filtros. (D) Risks perceived outside their home according to age: primary school and secondary school. 
protected staircases. An interesting fact is that $37 \%$ of the adolescents from Morales and Lomas de los Filtros and 9\% from Las Terceras perceived addictions as a health risk (Figure 1A) among these, the consumption of alcohol (Figure 2C).

The Figure 1 illustrates the categorization of risks that were perceived by the participants outside their homes according to study area: Las Terceras or Morales/Lomas de los Filtros (Figure 1C) and age: primary school or secondary school (Figure 1D). With regard to the situation outside participants' homes, respondents perceived in particular waste and soil pollution, water and air pollution, dangerous items, and animals and pests as harmful to their health (Chart 1, Figure 3). A statistically significant difference between the study areas can be found for instance in the category vandalism (Figure 1C). In Morales/ Lomas de los Filtros, $41 \%$ of the students took photographs in this category outside their homes (Figure 3A), as compared to only $9 \%$ of the participants from Las Terceras. A statistical significance also exists in the category air and water pollution; $82 \%$ of students in Las Terceras as compared to only $37 \%$ in Morales/Lomas de los Filtros took photographs in this category (Figure 1C). This can be explained due to the particular situation in Las Terceras, as people are exposed to extreme air pollution as a result of the operation of brick-kilns (Figure 3B). Besides the statistically significant differences already mentioned, a statistical significance exists in the categories animals and pests, waste and natural resources, dangerous items, and traffic (Figure 1C).

The frequency analysis furthermore demonstrates that that participants' age influences risk perception. Figure 1B illustrates the results of the photography project for the risks perceived at home according to age group. Results indicate that overall, more students from secondary school than primary school students perceived risks in the different categories. A statistical significance was detected for the categories activities and habits, waste and soil pollution, and lack of hygiene (Figure 1B). Whereas a lack of hygiene at home was perceived by $12 \%$ of secondary school students, none of the primary school students addressed this issue. Additionally 45\% secondary school students perceived waste and soil pollution as a health risk at home, compared to only $5 \%$ of primary school students (Figure 1B, Figure 2D).

Results for the scenario "outside home" furthermore demonstrate that a statistical significance regarding age exists in the categories waste and soil pollution, dangerous items and road traffic (Figure 1D). The issue of road traffic is a particularly interesting case. Twenty percent of the primary school students identified road traffic as a health risk as opposed to none of the students from secondary school. This indicates that older students have possibly learnt to deal with traffic insecurity, and do not consider it a risk to their personal well-being anymore.

In the following, some of the issues that were identified by the respondents are discussed in more detail in order to understand the perceptions and concerns behind them. Frequency analysis for instance indicated that most participants from Las Terceras felt negatively affected by air pollution outside their homes, and even at home. As schools and houses are situated within the direct vicinity of the brick-making facilities, this results in a high exposure of residents to extreme air pollution (Figure 3B). Participants observed for instance that when they open the windows, smoke from the brick-kilns gets inside the house. Hence, respondents expressed an awareness of and concern with the lack of separation of working and living space. Furthermore, students were aware of the negative health impact caused by the levels of air pollution. However, they linked the issue of air pollution mostly to respiratory diseases but none of the participants mentioned other health issues such as an increased cancer risk.

Another issue, which was raised concerning the brick-making business, was the apparent ignorance of the local population. One respondent for instance explained that she took the photograph of the brick-kiln to show how little people care, the little they care about their health; there are houses close by and children playing. Furthermore, participants expressed concern about with the effect of the air pollution on the environment: the brick-kilns are bad because they cause injuries to the lungs and to the plants and every living being. Yet, even though most participants also exhibited a general desire to remove the brickkilns from the urban area to less populated areas, they were also aware of the fact that they provide a basic income for most of the families: Many brick-makers feel that they have no other way to provide for their families. For them the brickkilns are the only way to make a living since they have no education and there is no other work. This illustrates the tension between the harm that is caused to people's health and the environment and dependence on the brick-making business for people's livelihood.

Another issue that was raised in both study areas is issue of animals and pests (Figure 3C), 

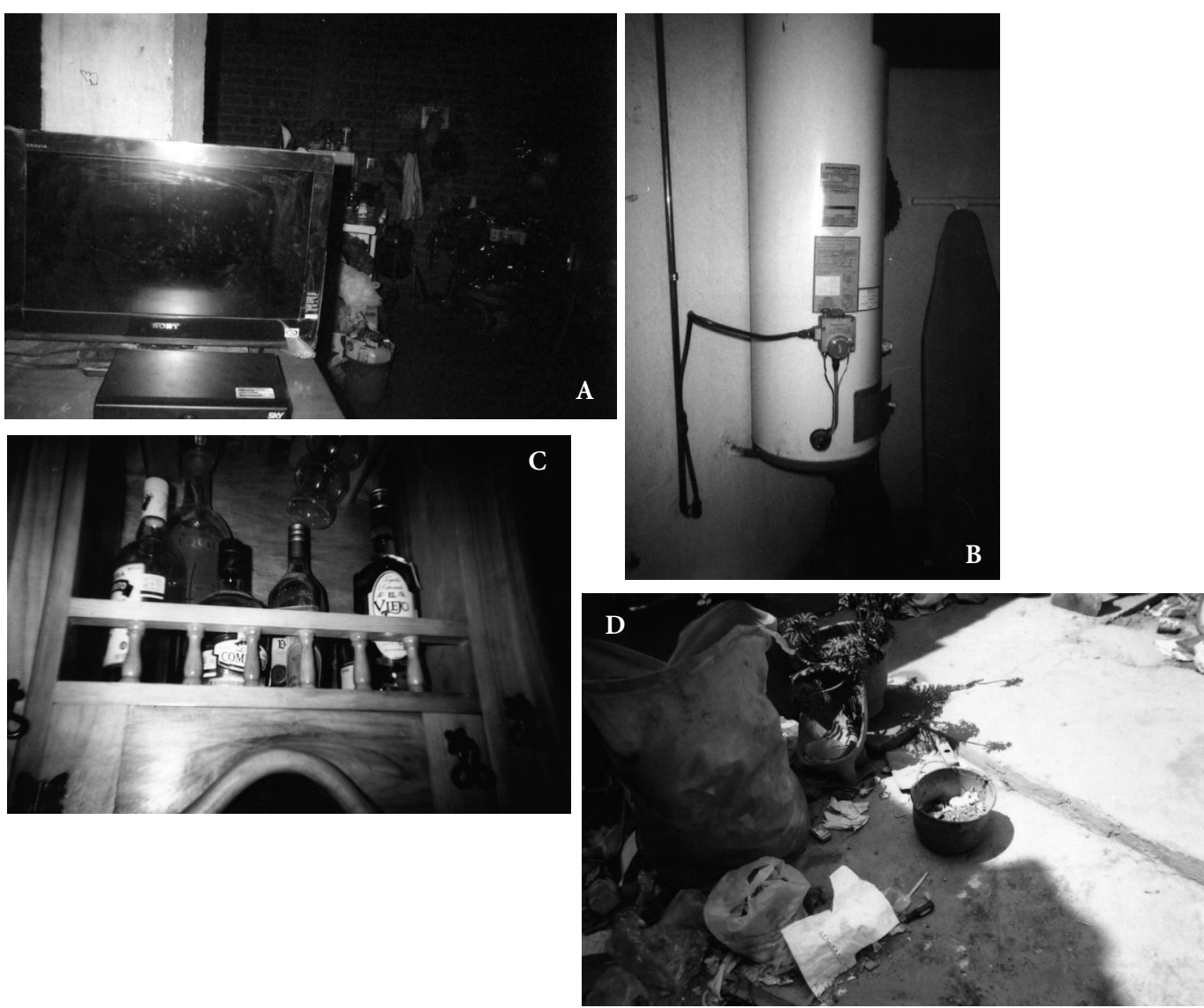

Figure 2. Examples of photographs of risks perceived by the students inside their homes: (A) Exposure to communication technology (television) (B) Exposure to hazardous items (boiler) (C) Addictions (alcoholic drinks) (D) Exposure to waste.

which are considered harmful to people's health. While most respondents referred to stray dogs, others also mentioned rats, pigs kept by families as livestock, and snakes. Generally, stray dogs were considered dirty, and students observed that they carried diseases and could infect people around them. Furthermore, respondents considered that pigs were dirty and smelly, and that it was not hygienic to keep them inside the house, since this was not a farm but, it is a neighborhood like any other. At the same time, respondents made a link between inadequate waste disposal and the presence of pests. Respondents argued that the wild garbage dumps might for instance attracts rats.

Generally, participants assumed a critical position concerning the waste problem. Yet, it becomes clear that, independent of age or study area, students wished to live in a clean environment. One student observed: I would like you to see the circumstances that we live in, and I want people to get punished for throwing their waste on the street. I want to live in a community without dirt. Respondents from both communities complained about the careless behavior of people from the neighborhoods, who just throw their waste on the street. In Las Terceras respondents furthermore explained that people tend to pile up unused items such as old furniture and mattresses on the street (Figure 3D). In general, the impression was conveyed that most people in both neighborhoods do not care enough about issues of environmental health - neither outside their homes nor at home. With regard to the situation at home, some respondents criticized for instance the lack of hygiene and the exposure to hazardous items such as loose cables and open fire.

Yet, participants seemed to find it difficult to improve the situation due to a general igno- 

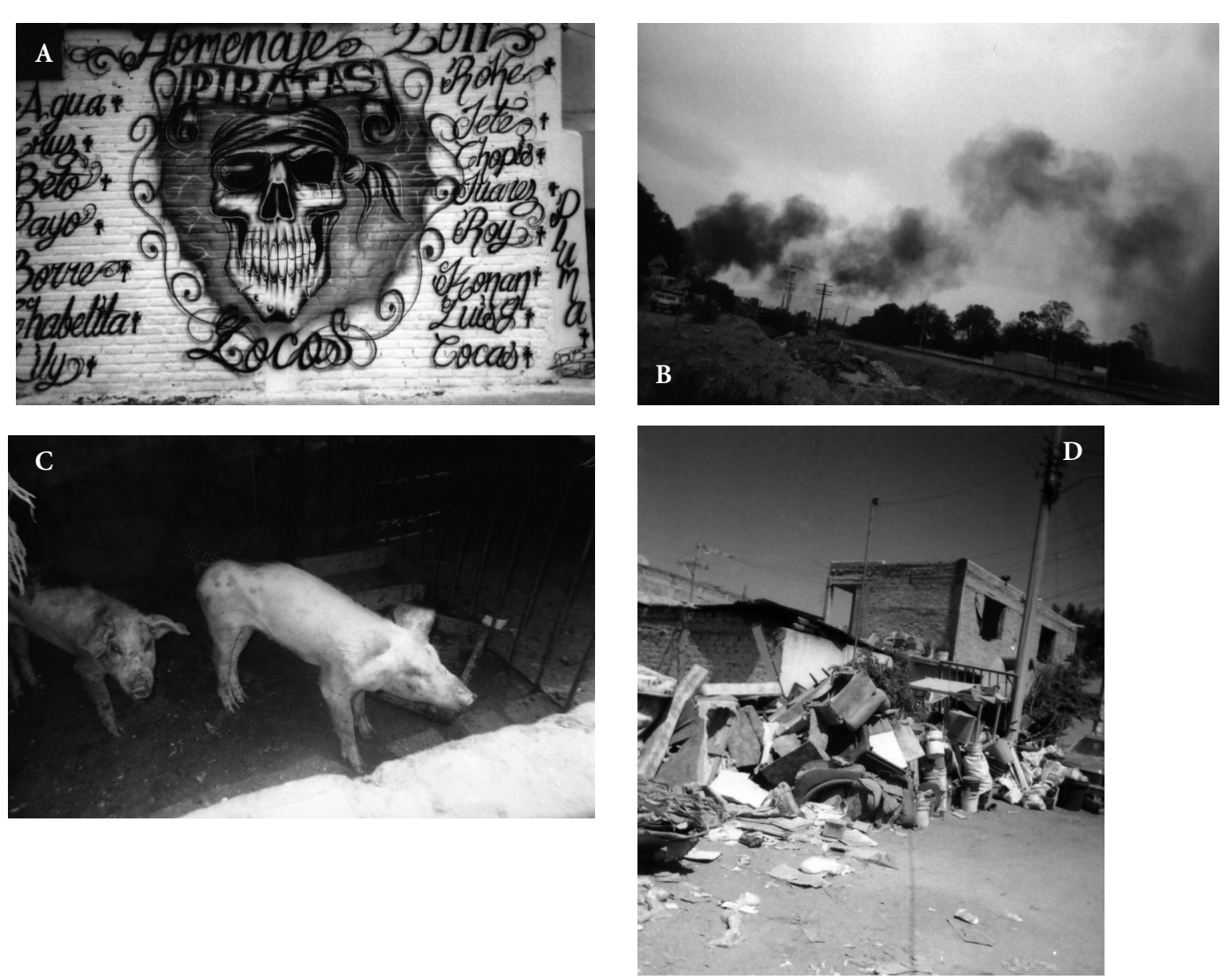

Figure 3. Examples of photographs of risks perceived by the students outside their homes (A) Vandalism in Morales (B) Air pollution due to the operation of brick-kilns in "Las Terceras" (C) Pigs kept by families in "Las Terceras" (D) Waste in the streets of "Las Terceras".

rance among the residents. One student argued that people should get punished for throwing their waste on the street. Others indicated that people should make a basic contribution by saving water, polluting less and recycling. However, even though most of the respondents expressed that they would like to live in a clean environment, only very few mentioned how this could be achieved. In this sense, a local risk communication program could not only provide information on environmental health risks in the communities, but it could also provide alternatives while actively engaging the population in the process.

Finally, Figure 4 illustrates the results of the SWOT analysis, which was conducted to analyze whether the photography technique provides meaningful results and is appropriate for engaging adolescents in community-based environmental risk research. The analysis indicated that the photography techniques allowed a realistic reflection of the individual concerns and perceptions. Furthermore, it helped participants adopt a critical perspective on their local environment. However, the success of the technique is very much dependent on the responsibility of the adolescents outside the classroom and the willingness of parents and teachers to allow their participation in the first place.

\section{Discussion}

Study results demonstrate that adolescents in both communities were remarkably aware of existing environmental health risks. Even though risk perception was partly influenced by the study area as well as by participants' age, it can be concluded that overall, participants recognized many of the health risks that had been identified 


\begin{tabular}{|c|c|}
\hline STRENGTHS & WEAKNESSES \\
\hline $\begin{array}{l}\text { - Allows the transmission of complex information } \\
\text { - Enables the realistic reflection of concerns and } \\
\text { perceptions } \\
\text { - Stimulates the creative participation and self- } \\
\text { expression of children and adolescents } \\
\text { - Overcomes age and language barriers } \\
\text { - The written photo-guide facilitates the interpretation } \\
\text { and provides important information on the context }\end{array}$ & $\begin{array}{l}\text { - Time- consuming and cost-intensive technique } \\
\text { - Relies on the responsibility of the participants } \\
\text { outside the classroom } \\
\text { - Lack of control and risk of interference of others } \\
\text { - It is difficult to depict sensitive risk contexts }\end{array}$ \\
\hline OPPORTUNITIES & THREATS \\
\hline $\begin{array}{l}\text { - Integration of techniques into school curriculum } \\
\text { may foster creative education strategies } \\
\text { - Participants adopt a critical perspective on their } \\
\text { community } \\
\text { - Engages young people in participatory research } \\
\text { - Fosters a dialogue between people from various } \\
\text { backgrounds }\end{array}$ & $\begin{array}{l}\text { - Refusal of parents to let their children participate } \\
\text { - Exposure to risk situations when taking photographs } \\
\text { of people in the street without their permission } \\
\text { - Technical problems regarding the operation of the } \\
\text { cameras }\end{array}$ \\
\hline
\end{tabular}

Figure 4. SWOT analysis of the photography technique.

in previous studies ${ }^{17-21}$. A local risk communication program should, however, also take account of the particular knowledge gaps. None of the students from Morales/Lomas de los Filtros for instance mentioned the presence of the metallurgical industrial plant as a health concern. A possible explanation for this is that air pollution in Morales/Lomas de los Filtros is not directly 'visible' as compared to the case of Las Terceras where air pollution by the brick-making kilns appears to be a more tangible issue. Furthermore, the natural groundwater contamination with fluoride, another 'invisible' issue, was not perceived by the participants from either of the communities. Hence, the risk perception analysis indicates some of the needs which a future risk communication program in the communities should address. At the same time, the adolescents identified some additional health risks that had not been spotted previously, such as the excessive use of communication technologies.

The study results furthermore illustrate that the photography technique is well-suited to analyze environmental risk perception when working with adolescents since it produces community narratives that give voice to the individuals and describe the local context in a comprehensive way $^{27}$. In line with the observations made by Micheal Lesy, our study showed that the photographs captured and transmitted complex information, which often cannot be expressed in words ${ }^{11}$. Hence, they portrayed an individual perspective, which enables access to the interior reality of the human being ${ }^{28}$. Furthermore, our study has confirmed the ability of the technique to overcome language or cultural barriers ${ }^{14}$.

The major strength of our study is the application of the photography technique to the field of risk perception analysis within the tradition of qualitative research which aims at exploring individual perceptions of reality ${ }^{29}$. Results demonstrated that the technique makes it possible to record and analyze complex personal risk perceptions in a concise and realistic manner. Apart from the images themselves, the written description of each photograph offered valuable information on the participants' personal background and specific knowledge. Participants conveyed a detailed perspective of the factors which they believed may affect their well-being, while sharing their personal concerns and providing a detailed description of their personal living environment. This can be considered a clear advantage in comparison to previous studies which relied on drawings to capture young peoples' individual perceptions of environmental health risks ${ }^{18,21,22,30,31}$. Whereas drawings tend to give room to differing interpretations, the photographs and the accom- 
panying written description made it possible to analyze individual narratives in a succinct way. Furthermore, the researcher bias and the subjectivity of analysis were considerably reduced. Students' behavior also clearly indicated that the photography technique stimulated their motivation, their responsibility and self-expression as well as their capacity to concentrate, to observe and to analyze.

Yet, it must be observed that a central weakness of the photography technique, as applied in the present study, regards the fact that it is a very demanding research tool, both in financial resources and time. Furthermore, some issues such as violence or drug abuse may hardly be documented in photographs, which may cause a distortion of the results. External threats to the technique may arise from the refusal of authorities and parents to allow participation in the project. Participants may also be exposed to risks while taking the photographs in case they take photos of people on the street without their permission (Figure 4).

Weaknesses and threats can be minimized by providing participants with an explanation on the operation of cameras as well as possible risks. This includes warning participants against taking photographs of strangers without their permission. Another important aspect is the development of personal relationships between researchers and community authorities in order to create trust and to foster support. In the case of working with local schools, creating ties with teachers and headmasters may also be favorable for integrating project results into the school curriculum, hence creating opportunities for longterm learning.

To conclude, despite its limitations, the photography technique can be considered a very adequate tool for engaging adolescents in environmental health research on local risk perception. It opens up a promising field for qualitative research on environmental health problems in local communities. We consider that the technique may assume an important role in particular for purposes of environmental education, and quality of life, making it possible to teach adolescents about exposure to environmental health risks in a participatory way while stimulating the individual capacities of the participants. It was furthermore argued that knowing the risk perception plays a crucial role in the development of local risk communication programs. The results of our study suggest that adolescents from both communities were aware of many environmental health risks which may compromise their health and well-being. Yet even so, some important risks in the study areas were not identified by the participants. Furthermore, differences in risk perception were identified according to age and study area. Based on the study results, we thus recommend the design of individually tailored local risk communication programs that address and respond to the differing needs. Among other issues they should focus on the problem of "hidden" risks such as the fluoridation of water which escaped students' risk perception. Furthermore, they should build on participants' knowledge and assessment concerning the environmental risk context, hence addressing issues such as soil and air pollution, leisure habits and exposure to dangerous items that were identified by the students themselves as some of the main determinants of health and well-being.

\section{Collaborations}

S Börner, JC Torrico Albina, LM Nieto Caraveo, and AC Cubillas Tejeda have participated in all the stages of the elaboration of this article. 


\section{References}

1. Chelala C. Impacto del ambiente sobre la salud infantil. Salud infantil ambiental. Washington: Panamerican Health Organization; 1999.

2. World Health Organization (WHO). Environmental Health 2013. [cited 2013 Dec 2]. Available from: http:// www.who.int/topics/environmental_health/en/.

3. Bolte G, Tamburlini G, Kohlhuber M. Environmental inequalities among children in Europe - evaluation of scientific evidence and policy implications. Eur Journal Public Health 2010; 20(1):14-20.

4. Silveira M, Almeida J, Silveira R, Conceição R, Barros A, Marcopito L. Qualidade de vida entre adolescentes: estudo seccional empregando o SF-12 Cien Saude Colet 2013; 18(7):2007-2015.

5. Irwin LG, Siddiqi A, Hertzman C. Early Child Development. A Powerful Equalizer. In: World Health Organization (WHO). Final Report for the World Health Organization's Commission on the Social Determinants of Health. Geneva: WHO; 2007.

6. Briones Gamboa F. La complejidad del riesgo: breve análisis transversal. Rev Univ Cristóbal Colón 2007; 20:9-19.

7. Wiedemann PM. Introduction to risk perception and risk communication. Jülich: Programme Group Humans, Environment, Technology (MUT), Research Center Jülich; 1993.

8. Choconi G. Comunicación de Riesgo, una aproximacion conceptual [working paper]. 2010. [cited 2013 Dec 2]. Available from: http://www.ambiente.gov.ar/archivos/ web/UERA/file/0910_comunic_riesgo_UERA.pdf.

9. Hart R. Children as the makers of a new geography. In: Karsten L, Bongertman T, De Haan G, Van der Straaten G, Tom I, editors. Building Identities: Gender Perspectives on Children and Urban Space. Amsterdam: Universiteit van Amsterdam; 1995. p. 41-47.

10. Hidalgo-Rasmussen C, Rajmil L, Montaño R. Adaptación transcultural del cuestionario KIDSCREEN para medir calidad de vida relacionada con la salud en población mexicana de 8 a 18 años. Cien Saude Colet 2014; 19(7):2215-2224.

11. Álvarez-Gayou Jurgenson JL. Cómo hacer investigación cualitativa. México: Editorial Paidós Mexicana. SA; 2010.

12. Dinklage R. American and German children's perceptions of war and peace: a photo-communication approach [thesis]. Gainesville: Universidad de Florida; 1986.

13. Fernández-Villanueva C, Revilla Castro JC, Domínguez-Bilbao R, Ferreira-Salles LM, Adam de Paula e Silva JM. 2011. Representaciones imaginarias de la interacción y violencia en la escuela. Athenea Dig 2011; 11(3):51-78.

14. Corona-Berkin S. Postales de la diferencia. La ciudad vista por fotógrafos wixáritari. Culturas Populares de México. México: Conaculta; 2011.

15. México. Consejo Nacional de Población. Zona Metropolitana de San Luis Potosí - Soledad de Graciano Sánchez. Grado de marginación por AGEB urbana 2005. [cited 2013 Dec 2]. Available from: http://conapo.gob.mx/ publicaciones/IMU2005/mapas/60-ZM_SLP_SGS.PDF

16. México. Secretaría de Ecología y Gestión Ambiental. Guía para la elaboración de los términos de referencia del parque ladrillero en San Luis Potosí, México. Ayuntamiento de San Luis Potosí: Secretaría de Ecología y Gestión Ambiental; 2004
17. Domínguez-Cortinas G, Díaz-Barriga F, Martínez-Salinas R, Cossío P, Pérez-Maldonado IN. Exposure to chemical mixtures in Mexican children: high-risk scenarios. Environ Sci Pollut Res 2013; 20(1):351-357.

18. Torres-Nerio R, Domínguez-Cortinas G, van't Hooft A, Díaz-Barriga F, Cubillas-Tejeda AC. Análisis de la percepción de la exposición a riesgos ambientales para la salud, en dos poblaciones infantiles, mediante la elaboración de dibujos. Salud colect 2010; 6(1):65-81.

19. Carrizales L, Razo I, Téllez-Hernández J, Torres-Nerio R, Torres A, Batres LE, Cubillas AC, Díaz-Barriga F. Exposure to arsenic and lead of children living near a copper-smelter in San Luis Potosi, Mexico: Importance of soil contamination for exposure of children. Environ Res 2006; 110(1):1-10.

20. Flores-Ramírez R, Rico-Escobar E, Núñez-Monreal J, García-Nieto E, Carrizales L, Ilizaliturri-Hernández C, Díaz-Barriga F. Exposición infantil al plomo en sitios contaminados. Salud pública México 2012; 54(4):383392.

21. Cubillas-Tejeda AC, Torres-Nerio R, Díaz-Barriga Martínez F, Carrizales-Yáñez L, Coronado-Salas C, Nieto-Caraveo LM, Moreno-Sánchez AR, Barraza-Lomelí L. Diseño y Aplicación de un Programa de Comunicación de Riesgos para la Salud Ambiental en un Sitio Contaminado con Plomo y Arsénico. Cien Saude Colet 2011; 16(10):4115-4126.

22. Coronado-Salas C, Díaz-Barriga Martínez F, Moreno-Sánchez AR, Carrizales Yáñez L, Torres-Nerio R, Cubillas-Tejeda AC. La comunicación de riesgos como una herramienta para disminuir la exposición infantil a plomo y arsénico en la zona contaminada de Villa de la Paz-Matehuala, San Luis Potosí, México. Rev Int Contam Ambie 2012; 28(2):167-181.

23. López-Noguero F. El análisis de contenido como método de investigación. Rev Educ 2002; 4:167-179.

24. Mayring P. Qualitative Inhaltsanalyse. Grundlagen und Techniken. Weinheim: Deutscher Studienverlag; 2000.

25. Schreier M. Qualitative Content Analysis in Practice. London: Sage Publications Ltd.; 2012.

26. Moreno-Altamirano A, López-Moreno S, Corcho-Berdugo A. Principales medidas en epidemiología. Salud Pública México 2000; 42(4):337-446.

27. Brown P. Qualitative methods in environmental health research. Environ Health Perspect 2003; 111(14):17891798.

28. Buck-Morss S. Estudios visuales e imaginación global. Antípoda 2009; 9:19-46.

29. Kangsen Scammell M. Qualitative Environmental Health Research: An Analysis of the Literature, 19912008. Environ Health Perspec 2010; 118(8):1146-1154.

30. Barraza L. Children's drawings about the environment. Environ Educ Res 1999; 5(1):1-17.

31. Piko BF, Bak J. Children's perceptions of health and illness: images and lay concepts in preadolescence. Health Educ Res 2006; 21(5):643-653.

Article submitted 06/06/2014

Approved 15/10/2014

Final version submitted 17/10/2014 


\section{Ciência \& Saúde Coletiva}

volume 20 número 5 - 2015

p. 1618,

onde se lê:

require, allow understanding their perspective through stimulate a meaningful

leia-se:

which allow understanding their perspective through stimulating

p. 1622,

onde se lê:

these, the consumption

leia-se:

these figuring the consumption

p. 1626,

leia-se:

\section{Acknowledgments}

We thank the Fondo Sectorial de Investigación en Salud y Seguridad Social from the Consejo Nacional de Ciencia y Technología (CONACyT) in Mexico for their financial support through the project SALUD-142064. We thank the Deutscher Akademischer Austausch Dienst (DAAD) in Germany for providing funding for the research. Furthermore, we thank all the adolescents who participated in the project. 